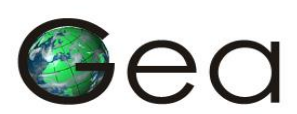

JURNAL PENDIDIKAN GEOGRAFI

\title{
PENGARUH METODE SIMULASI DAN DEMONSTRASI TERHADAP PEMAHAMAN KONSEP BENCANA TANAH LONGSOR (Study Eksperimen Pada Peserta Didik Kelas X SMA Negeri 1 Sirampog )
}

\author{
Ady Priyono, S.Pd \\ Program Studi Magister Pendidikan Geografi \\ Universitas Pendidikan Indonesia
}

\begin{abstract}
ABSTRAK
Salah satu kompetensi dasar geografi yang harus dikuasai siswa kelas $\mathrm{X}$ adalah kompetensi Menganalisis dinamika dan kecenderungan perubahan litosfer dan pedosfer serta dampaknya terhadap kehidupan di muka bumi dengan topik mitigasi bencana yang secara kebetulan daerah penelitian merupakan daerah labil dengan potensi tanah longsor dan amblasan tanah. Untuk itu diperlukan metode pembelajaran yang tepat dalam penanaman konsep tanah longsor tersebut. Metode yang akan diteliti adalah metode demonstrasi dan metode simulasi. Berapa besar pengaruh metode ini menjadikan timbul pertanyaan penelitian;1)Apakah terdapat perbedaan pemahaman konsep bencana tanah longsor pada peserta didik dikelas yang tidak menggunakan metode simulasi sebelum dan sesudah perlakuan diberikan (pretes - posttest) ? "2)Apakah terdapat perbedaan pemahaman konsep bencana tanah longsor pada peserta didik dikelas yang menggunakan metode simulasi sebelum dan sesudah perlakuan diberikan (pretes - posttest)?"3)Apakah terdapat perbedaan pemahaman konsep bencana tanah longsor pada peserta didik dikelas yang menggunakan dan tidak menggunakan metode simulasi sesudah perlakuan diberikan (posttest) ? Penelitian ini menggunakan pendekatan kuantitatif dengan desain quasi eksperimen (Quasi exsperiment design) dengan pengukuran dua faktor dalam versi faktorial pretes - posttest nonequivalent control group design .Sampel diambil dua kelas dari tiga kelas pada populsi penelitian yang memiliki karakteristik nilai yang tidak terlalu jauh. Instrument yang digunakan dalam penelitian ini adalah instrumen tes untuk variabel 1 dan 2 . Perhitungan statistik yang digunakan adalah statistik non parametrik (Two Related Samples Test dan Two Independent Samples Test) dan statistik parametrik (Paired Samples T Test). Hasil penelitian ini menjawab semua pertanyaan penelitian dan membuktikan hipotesis yang diajukan. Pertama, Ada perbedaan hasil tes antara pretes dan posttes yang yang diperoleh pada peserta didik dikelas pada kelas eksperimen yang menggunakan metode simulasi dengan signifikansi 0,032. Kedua, Ada perbedaan hasil tes antara pretes dan posttes yang yang diperoleh pada peserta didik dikelas pada kelas eksperimen yang menggunakan metode simulasi signifikan 0,00 .Ketiga, Ada perbedaan hasil belajar pada kelas eksperimen yang menggunakan metode simulasi (PostSimulasi) dan kelas kontrol yang menggunakan metode demonstrasi (PostDemonstrasi) dengan nilai Mean Rank Metode Simulasi sebesar 22,14 dan Mean Rank metode Demonstrasi sebesar 45. Jadi hasil belajar pada kelas kontrol yang menggunakan metode demonstrasi lebih besar dari pada metode simulasi.
\end{abstract}

Kata Kunci: Pemahaman Konsep, Metode Simulasi, Metode Demonstrasi 


\section{PENDAHULUAN}

Sekolah memiliki peran strategis dalam mendidik dan memberikan materi mitigasi bencana sejak dini yakni mulai dari tingkatan SD, SMP dan SMA. Menurut hasil dari penelitian LIPI dan UNESCO (2006) kedudukan sekolah menjadi sangat penting karena faktorfaktor di bawah ini antara lain :

1. Sekolah secara sadar dan terencana melakukan upaya mewujudkan suasana belajar dan proses pembelajaran.

2. Sekolah tetap terpercaya sebagai wahana efektif untuk membangun budaya bangsa.

3. Sekolah merupakan 'ruang publik' dengan tingkat kerentanan tinggi

Sebuah penelitian Maryani menyatakan (2009:12) bahwa "Pengetahuan tentang kebencanaan para guru, kepala sekolah dan dewan sekolah ternyata umumnya tidak dipahami dengan baik, mencapai $70 \%$ dari responden menyatakan sedikit dan tidak paham tentang peristiwa kebencanaan". Hal ini sangat mengenaskan padahal wilayah Indonesia sebagian besar adalah wilayah rawan bencana.

Melalui pembelajaran mitigasi bencana diharapkan peserta didik memiliki tingkat kesiapsiagaan yang tinggi terhadap bencana alam yang dapat muncul sewaktu-waktu. Kesiapsiagaan itu sendiri diharapkan akan dapat disadari oleh diri sendiri dan pada gilirannya akan disampaikan kepada orang - orang terdekat terutama keluarga dan kepada orang - orang yang berada di sekitar lingkungan tempat tinggal peserta didik.

Beberapa pakar telah melakukan penelitian dan analisa tentang pentingnya mitigasi bencana. Berdasarkan penelitian yang telah dilakukan Laksono (2008:2) dikatakan bahwa “ materi mitigasi bencana disekolah dapat diberikan dengan dua cara yaitu metode infusi dan metode block". Metode infusi memadukan muatan dan proses pendidikan lingkungan dengan kurikulum yang ada sedangkan metode block adalah pembelajaran dengan berdiri sendiri. Masing- masing metode memiliki kelemahan dan kelebihan. Misalnya apabila mitigasi diberikan secara mandiri maka beban mata pelajaran menjadi semakin banyak. Model infusi berarti menyisipkan dalam materi-materi pelajaran di sekolah. Pelajaran yang sangat erat kaitannya adalah pelajaran geografi.

Banyak faktor yang mempengaruhi keberhasilan dalam pembelajaran diantaranya adalah metode pembelajaran. Bahkan Rusli (2010:1) menyatakan bahwa "Keberhasilan dari proses pendidikan sangat ditentukan oleh metode pembelajaran yang dilakukan oleh seorang pendidik apakah itu guru maupun dosen". Dalam arti bahwa Bila metode pembelajaran yang digunakan 
oleh seorang dosen tepat, maka dapat dipastikan perhatian, motivasi, maupun semangat peserta didik dalam mengikuti kegiatan pembelajaran akan selalu terdorong.

Pemilihan metode biasanya tergantung bobot materi pembelajaran geografi. Sumaatmadja (1997:73) menyatakan bahwa "dalam proses belajar mengajar geografi metode ceramah menjadi metode dasar yang sukar untuk ditinggalkan.” Hal ini memang menjadi kebiasaan lama guru di Indonesia. Siswa sendiri pun juga menjadi terbiasa dengan metode ini sehingga jika seorang guru mengubahnya menjadi metode lain, menjadi hal yang sukar untuk diterima. Padahal banyak metode lain yang dapat dilakukan dalam pembelajaran geografi. Agar penelitian lebih terarah rumusan masalah tersebut dapat dijabarkan menjadi beberapa pertanyaan penelitian sebagai berikut:

1. Apakah terdapat perbedaan pemahaman konsep bencana tanah longsor pada peserta didik dikelas yang tidak menggunakan metode simulasi sebelum dan sesudah perlakuan diberikan (pretes - posttest)?

2. Apakah terdapat perbedaan pemahaman konsep bencana tanah longsor pada peserta didik dikelas yang menggunakan metode simulasi sebelum dan sesudah perlakuan diberikan (pretes - posttest)?

3. Apakah terdapat perbedaan pemahaman konsep bencana tanah longsor pada peserta didik dikelas yang menggunakan dan tidak menggunakan metode simulasi sebelum perlakuan diberikan (pretes)?

4. Apakah terdapat perbedaan pemahaman konsep bencana tanah longsor pada peserta didik dikelas yang menggunakan dan tidak menggunakan metode simulasi sesudah perlakuan diberikan (posttest)?

\section{METODE PENELITIAN}

Penelitian ini mengunakan pendekatan kuantitatif dengan desain quasi eksperimen (Quasi exsperiment design). Metode eksperimen sebagai suatu situasi penelitian yang sekurangnya memiliki 1 variabel yang sengaja dimanipulasi peneliti. Salah satu ciri dari penelitian dengan menggunakan eksperimen quasi adalah adanya kelompok kontrol sebagai garis dasar untuk dibandingkan dengan kelompok eksperimen Penelitian ini menggunakan desain eksperimen semu dengan pengukuran dua faktor dalam versi faktorial pretes - posttest nonequivalent control group design (Sugiyono : $2011: 116$ ) 


\section{LANDASAN TEORI}

Dalam hal metode tersebut seorang ahli yang bernama Edgar Dale yang mengemukakan tentang Kerucut Pengalaman (Cone of Experience) yang terlihat dalam gambar berikut :

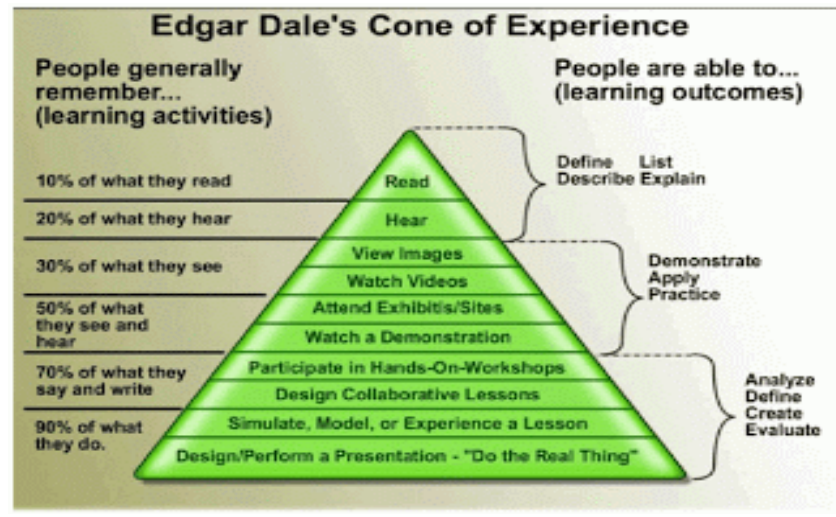

Gambar 2.1 Kerucut Pengalaman

Dari gambar tersebut dapat dijelaskan bahwa rentangan tingkat pengalaman dari yang bersifat langsung hingga ke pengalaman melalui simbol-simbol komunikasi dari yang bersifat kongkrit ke abstrak. Dikatakan lebih lanjut bahwa nilai media dalam pembelajaran diklasifikasikan berdasarkan nilai pengalaman yang terbagi atas dua belas tingkatan dengan kriteria yang paling tinggi nilainya adalah pengalaman yang paling konkret, sedangkan yang paling bawah adalah yang paling abstrak dan selanjutnya dinamakan sebagai "Kerucut Pengalaman". Kerucut pengalaman dapat dijelaskan sebagai berikut :

1. Direct purposeful experience (Pengalaman langsung)

Pengalaman yang diperoleh dari hasil kontak langsung dengan lingkungan, objek, binatang, manusia dan sebagainya. tahap ini pembelajaran dilakukan dengan cara memegang, merasakan atau mencium,atau melihat langsung obyek materi pelajaran.

2. kontak melalui model, benda tiruan atau simulasi (contrived expence).

Tahap ini kekongkritan sudah dikurangi namun pemikiran mulai dilaksanakan dengan membuat simulasi benda/miniatur tertentu yang menjelaskan pada objek yang dikaji.

3. Dramatized Experience Verbal Symbol.

Pengalaman yang diperoleh melalui permainan (permainan pengajaran), sandiwara boneka, permainan peran, drama soaial atau psikologis. Karena dengan 
drama si pembelajar dapat menjadi semakin merasakan langsung materi yang dipelajarkan.

4. Demonstration ( pengalaman yang diperoleh melalui pertunjukkan).

Demonstrasi disini merupakan gambaran dari suatu penjelasan yang merupakan sebuah fakta atau proses. Seorang demonstrator menunjukkan bagaimana sesuatu itu bisa terjadi. Misalnya seperti seorang guru geografi yang mendemonstrasikan terjadinya erosi.

5. Study Trips

Pengalaman belajar yang yang diperoleh melalui karyawisata. Jika kita berkarya wisata, biasanya kita melihat kegiatan apa yang sedang dikalukan orang llain. Dalam karya wisata ini pebelajar mengamati secara langsung dan mencatat apa saja kegiatan mereka. Pembelajar lebih mengandalkan pengalaman mereka dan pemelajar tidak perlu memberikan banyak komentar, biarkan mereka berkembang sendiri

6. Exhibition

Pengalaman belajar yang diperoleh melalui pameran. Dalam hal ini siswa mendapatkan pengalaman dari kegiatan yang diperoleh dari objek yang dipamerkan.

7. Education $T V$

Pengalaman yang diperoleh melalui televisi pendidikan. Pada masa sekarang sudah ada stasiun TV yang khusus menyiarkan tatang pendidikan.

8. Motion Picture

Pengalaman yang diperoleh melalui gambar atau film hidup atau bioskop. Peserta didik pada saat sekarang dengn mudahnya mengubduh motion picture melalui media internet.

9. Still Picture

Pengalaman yang peroleh melalui gambar mati, slide, atau fotografi.

10. Radio dan Recording

Pengalaman yang diperoleh melalui siaran radio atau rekaman suara (audio recording).

\section{Visual Symbol}

Pengalaman yang diperoleh melalui simbol yang dapat dilihat seperti grafik, bagan atau diagram.

12. Verbal Symbol 
Pengalaman yang diperoleh melalui penuturan dengan kata-kata.

Dari kerucut yang di ajukan oleh Edgar Dale digambarkan tentang arti dan dalamnya pengalaman yang diperoleh berdasarkan tingkatan. Jadi pengalaman nomor satu adalah yang paling tinggi nilainya dan nomor terakhir paling rendah. Dale berkeyakinan bahwa simbol dan gagasan yang abstrak dapat lebih mudah dipahami dan diserap manakala diberikan dalam bentuk pengalaman konkrit.

Dengan demikian dapat dikatakani bahwa pembelajaran yang hanya melalui kata-kata mempunyai nilai yang sangat rendah dalam alur pengalaman manusia. Oleh karena itu, agar pembelajaran dapat memberikan pengalaman yang berarti bagi anak, guru perlu memikirkan media yang pembelajaran yang dapat membawa anak/siswa kepada pengalaman yang lebih konkret.

Metode pembelajaran merupakan teknik menyampaikan materi pembelajaran kepada peserta didik dari rencana yang sudah disusun dalam kegiatan nyata agar tujuan yang telah disusun tercapai secara optimal.. Keberhasilan implementasi strategi pembelajaran sangat tergantung pada cara guru menggunakan metode pembelajaran, karena suatu strategi pembelajaran hanya mungkin dapat diimplementasikan melalui penggunaan metode pembelajaran.tidak ada metode yang paling ideal yang dapat digunakan untuk semua materi, karena tiap metode memiliki karakteristik kelebhan dan kekurangannya masing - masing.

Demonstrasi merupakan metode yang sangat efektif, sebab membantu peserta didik untuk mencari jawaban dengan usaha sendiri berdasarkan fakta atau data yang benar. Metode demonstrasi merupakan metode penyajian pelajaran dengan memperagakan dan mempertunjukkan kepada peserta didik tentang suatu proses, situasi atau benda tertentu, baik sebenarnya atau hanya sekadar tiruan. Sebagai metode penyajian, demonstrasi tidak terlepas dari penjelasan secara lisan oleh guru. Walaupun dalam proses demonstrasi peran peserta didik hanya sekadar memerhatikan, akan tetapi demonstrasi dapat menyaapabilan bahan pelajaran lebih konkret. Dalam strategi pembelajaran, demonstrasi dapat digunakan untuk mendukung keberhasilan strategi pembelajaran ekspositori dan inkuiri.

Simulasi berasal dari kata simulate yang artinya berpura-pura atau berbuat seakan-akan. Sebagai metode mengajar, simulasi dapat diartikan cara penyajian pengalaman belajar dengan menggunakan situasi tiruan untuk memahami tentang konsep, prinsip, atau keterampilan tertentu. Simulasi dapat digunakan sebagai metode mengajar dengan asumsi tidak semua proses pembelajaran dapat dilakukan secara langsung pada objek yang sebenarnya. Gladi resik 
merupakan salah satu contoh simulasi, yakni memperagakan proses terjadinya suatu upacara tertentu sebagai latihan untuk upacara sebenarnya supaya tidak gagal dalam waktunya nanti. Demikian juga untuk mengembangkan pemahaman dan penghayatan terhadap suatu peristiwa, penggunaan simulasi akan sangat bermanfaat.

\section{HASIL DAN PEMBAHASAN}

Bab ini akan membahas hasil penelitian yang telah dilakukan di SMA Negeri 1 Sirampog kecamatan Sirampog Kabupaten Brebes. Pengambilan data telah dilakukan untuk menguji tingkat pemahaman bencana tanah Longsor dengan membandingkan antara metode simulasi dan metode demonstrasi. Setelah melalui prosedur penelitian untuk pengujian validitas dan reliabilitas instrumen, hasilnya instrumen tersebut layak untuk dijadikan alat menguji pemahaman konsep tanah longsor dengan metode simulasi dan demonstrasi.

\section{Uji Prasarat Analisis}

\section{Normalitas Data}

Dalam sebuah penelitian dilakukan beberapa tahap sebelum data data dapat diteruskan pada tahap selanjutnya. Variabel yang ada dalam penelitian ini akan mengukur keabsahan data dengan uji normalitas data. Uji normalitas dilakukan untuk melihat tingkat kenormalan data yang digunakan, apakah data berdistribusi normal atau tidak. Tingkat kenormalan data sangat penting karena dengan data yang terdistribusi normal, maka data tersebut dianggap dapat mewakili populasi. Uji yang dipakai adalah uji Kolmogorov Smirnov (Liliefor) yang dihitung dengan program SPSS.

\section{Uji Homogenitas}

Uji homogenitas sebagai salah satu uji syarat analisa, selain uji normalitas dimaksudkan untuk memperlihatkan bahwa dua atau lebih kelompok data sampel berasal dari populasi yang memiliki varians yang sama. Uji homogenitas hasil pre test dengan data input hasil pre test kelas eksperimen dan kelas kontrol dilakukan pada dasarnya untuk membuktikan apakah data yang akan dianalisa itu memiliki varians yang sama atau tidak dalam setiap kelompoknya. Pengolahan data uji homogenitas hasil pretes menggunakan spss versi 17. Interpretasi yang dapat dilakukan dari outputnya adalah :

1) Dari tabel uji homogenitas ini yang digunakan adalah signifikansi nilai rata - rata (base mean) 
2) Uji homogenitas dilakukan dengan taraf signifikansi uji $\alpha=0,05$

3) Jika skor signifikasni hasil perhitungan $>\alpha=0.05$ maka data yang digunakan untuk analisa uji t selanjutnya pantas untuk dilanjutkan, artinya varian nilai tiap sampel dikedua kelompok dikatakan homogen. Jika hasil perhitungan nilai $\alpha=0,05$ maka data tersebut dinyatakan tidak homogen dan tidak dapat diteruskan untuk di uji pada tahap selanjutnya.

\section{Uji Hipotesis}

\section{Uji Hipotesis 1}

Uji Hipotesis 1 menggunakan analisis Parametrik yaitu Paired Samples T Test karena data variabel PreSimulasi dan PostSimulasi berdistribusi normal. Paired Samples T Test atau uji sampel berpasangan digunakan untuk menguji perbedaan rata-rata dari dua kelompok data atau sampel yang berpasangan.

Pada output pertama menjelaskan tentang statistik data yang berupa rata-rata yakni 16,86 untuk presimulasi dan 16,11 untuk postsimulasi, jumlah data $(\mathrm{N})$ untuk kelas Eksperimen adalah 35 siswa, standar deviasi 2.830 untuk presimulasi dan 2.111 untuk PostSimulasi dan standar error mean 0.478 untuk presimulasi dan 0.357 untuk postsimulasi. Untuk lebih lengkap dapat dilihat dalam tabel berikut :

Tabel 4.19 Paired Samples Statistics

\begin{tabular}{|ll|l|l|l|l|}
\hline & & Mean & N & Std. Deviation & Std. Error Mean \\
\hline Pair 1 & PreSimulasi & 16.86 & 35 & 2.830 & .478 \\
& PostSimulasi & 16.11 & 35 & 2.111 & .357 \\
\hline
\end{tabular}

Sumber : Hasil Perhitungan

Pada output kedua menjelaskan hasil korelasi dari sampel berpasangan yang terdiri dari jumlah data, nilai korelasi, dan signifikansi, signifikansi lebih dari 0,05 berarti tidak terjadi hubungan yang signifikan. Lebih lengkap dapat dilihat pada tabel dibawah ini.

Tabel 4.20 Paired Samples Correlations

\begin{tabular}{|ll|l|l|l|}
\hline & & N & Correlation & Sig. \\
\hline Pair 1 & PreSimulasi \& PostSimulasi & 35 & .722 & .000 \\
\hline
\end{tabular}

Sumber : Hasil Perhitungan 
Dan pada output ketiga menjelaskan hasil uji sampel berpasangan yang berupa nilai $\mathrm{t}$ hitung dan tingkat signifikansi dengan tingkat kepercayaan $95 \%$.

Tabel 4.21Paired Samples Test

\begin{tabular}{|c|c|c|c|c|c|c|c|c|c|}
\hline & \multicolumn{5}{|c|}{ Paired Differences } & \multirow[b]{3}{*}{$t$} & \multirow[b]{3}{*}{ df } & \multirow{3}{*}{$\begin{array}{l}\text { Sig. }(2 \\
\text { tailed })\end{array}$} \\
\hline & & \multirow{2}{*}{$\begin{array}{l}\mathrm{Me} \\
\mathrm{an}\end{array}$} & \multirow{2}{*}{$\begin{array}{l}\text { Std. } \\
\text { Deviation }\end{array}$} & \multirow{2}{*}{$\begin{array}{l}\text { Std. Error } \\
\text { Mean }\end{array}$} & \multicolumn{2}{|c|}{$\begin{array}{l}95 \% \text { Confidence } \\
\text { Interval of the } \\
\text { Difference }\end{array}$} & & & \\
\hline & & & & & Lower & Upper & & & \\
\hline Pair 1 & $\begin{array}{l}\text { PreSimulasi - } \\
\text { PostSimulasi }\end{array}$ & $\begin{array}{l}.74 \\
3\end{array}$ & 1.961 & .331 & .069 & 1.416 & 2.242 & 34 & .032 \\
\hline
\end{tabular}

Sumber : Hasil Perhitungan

Dapat diketahui bahwa signifikansi sebesar 0,032 lebih kecil dari 0,05 maka $\mathrm{H}_{0}$ ditolak. Kesimpulannya yaitu Ada perbedaan hasil tes antara pretes dan posttes yang yang diperoleh pada peserta didik dikelas pada kelas eksperimen yang menggunakan metode simulasi. Dari output tabel 1 dapat diketahui nilai Mean untuk PreSimulasi sebesar 16,86 dan PostSimulasi sebesar 16,11. Jadi PreSimulasi lebih besar dari PostSimulasi.

2. Uji hipotesis 2

Uji Hipotesis 2 menggunakan analisis Non Parametrik yaitu Two Related Samples Test karena data variabel PostDemonstrasi berdistribusi tidak normal. Analisis ini sebagai alternatif pengganti dari Paired Samples T Test jika data tidak normal.

Tabel 4.22 Wilcoxon Signed Ranks Test

\begin{tabular}{|ll|l|l|l|}
\hline \multicolumn{1}{|c|}{ Ranks } & N & Mean Rank & Sum of Ranks \\
\hline PostDemonstrasi - & Negative Ranks & $1^{\mathrm{a}}$ & 2.00 & 2.00 \\
PreDemonstrasi & Positive Ranks & $28^{\mathrm{b}}$ & 15.46 & 433.00 \\
& Ties & $0^{\mathrm{c}}$ & & \\
& Total & 29 & & \\
\hline
\end{tabular}

a. PostDemonstrasi < PreDemonstrasi

b. PostDemonstrasi > PreDemonstrasi

Tabel 4.23 Test Statistics ${ }^{b}$

\begin{tabular}{|l|l|}
\hline & PostDemonstrasi - PreDemonstrasi \\
\hline Z & $-4.683^{\mathrm{a}}$ \\
Asymp. Sig. (2-tailed) & .000 \\
\hline
\end{tabular}




\begin{tabular}{|ll|l|l|l|}
\hline \multicolumn{2}{|c|}{ Ranks } & N & Mean Rank & Sum of Ranks \\
\hline PostDemonstrasi - & Negative Ranks & $1^{\mathrm{a}}$ & 2.00 & 2.00 \\
PreDemonstrasi & Positive Ranks & $28^{\mathrm{b}}$ & 15.46 & 433.00 \\
& Ties & $0^{\mathrm{c}}$ & & \\
& Total & 29 & & \\
\hline
\end{tabular}

a. PostDemonstrasi < PreDemonstrasi

a. Based on negative ranks.

b. Wilcoxon Signed Ranks Test

c. PostDemonstrasi $=$ PreDemonstrasi

Sumber : Hasil Perhitungan

Pengujian yang dilakukan adalah Two Related Samples Test yang digunakan untuk mengetahui Apakah terdapat perbedaan hasil tes antara pretes dan posttes yang yang diperoleh pada peserta didik dikelas pada kelas kontrol yang menggunakan metode demonstrasi. Dapat diketahui bahwa signifikansi sebesar 0,000 lebih kecil dari 0,05 maka $\mathrm{H}_{0}$ ditolak. Kesimpulannya yaitu Ada perbedaan hasil tes antara pretes dan posttes yang yang diperoleh pada peserta didik dikelas pada kelas kontrol yang menggunakan metode demonstrasi.

\section{Hipotesis ketiga}

Uji Hipotesis 3 menggunakan analisis Non Parametrik yaitu Two Independent Samples Test karena data variabel PostDemonstrasi berdistribusi tidak normal. Analisis ini sebagai alternatif pengganti dari Independent Samples T Test jika data tidak normal. Two Independent Samples Test atau uji 2 sampel bebas digunakan untuk menguji perbedaan rata-rata dari dua kelompok data yang independen. Uji ini termasuk uji non parametrik yang tidak mensyaratkan data normal dan homogen. Dari output tabel 1 dapat diketahui bahwa nilai Mean Rank Metode Simulasi sebesar 22,14 dan Mean Rank metode Demonstrasi sebesar 45. Jadi hasil belajar pada kelas kontrol yang menggunakan metode demonstrasi lebih besar dari pada metode simulasi.

Tabel 4.24 Mann-Whitney Test

\begin{tabular}{|ll|l|l|l|}
\hline \multicolumn{2}{|c|}{ Metode } & $\mathrm{N}$ & Mean Rank & Sum of Ranks \\
\hline Hasil_Belajar & Metode simulasi & 35 & 22.14 & 775.00 \\
& Metode demonstrasi & 29 & 45.00 & 1305.00 \\
Total & 64 & & \\
\hline
\end{tabular}

Sumber : Hasil Perhitungan 
Tabel 4.25 Test Statistics ${ }^{\mathrm{a}}$

\begin{tabular}{|l|l|}
\hline & Hasil_Belajar \\
\hline Mann-Whitney U & 145.000 \\
Wilcoxon W & 775.000 \\
Z & -4.923 \\
Asymp. Sig. (2-tailed) & .000 \\
\hline
\end{tabular}

a. Grouping Variable: Metode

Sumber : Hasil Perhitungan

Dapat diketahui bahwa signifikansi sebesar 0,000 lebih kecil dari 0,05 maka $\mathrm{H}_{0}$ ditolak. Kesimpulannya yaitu Ada perbedaan hasil belajar pada kelas eksperimen yang menggunakan metode simulasi (PostSimulasi) dan kelas kontrol yang menggunakan metode demonstrasi (PostDemonstrasi). Dari output tabel 1 dapat diketahui bahwa nilai Mean Rank Metode Simulasi sebesar 22,14 dan Mean Rank metode Demonstrasi sebesar 45. Jadi hasil belajar pada kelas kontrol yang menggunakan metode demonstrasi lebih besar dari pada metode simulasi.

\section{PEMBAHASAN}

Keberhasilan pembelajaran di kelas ditentukan oleh banyak factor. Salah satu diantaranya adalah metode pembelajaran. Dalam pembelajaran khususnya pelajaran geografi, guru hendakah menghindari verbalisme. Banyak metode yang dapat digunakan dalam pembelajaran dan Dalam tiap metode belajar terdapat bermacam kegiatan namun tidak semua metode dapat digunakan untuk pokok bahasan yang sama. Sebagaimana dikemukakan oleh Nasution yang mengatakan pelajaran akan lebih menarik dan berhasil apabila dihubungkan dengan pengalaman - pengalaman dimana anak dapat melihat meraba mengucap berbuat mencoba berfikir dan sebagainya. Pelajaran tidak hanya bersifat intelektual melainkan juga bersifat emosional. Kegembiraan belajar dapat mempertinggi hasil belajar. Salah satu caranya yaitu dengan menggunakan alat peraga atau melalui permainan-permainan.

Hasil penelitian ini menunjukkan bahwa pemahaman konsep bencana tanah longsor lebih tepat menggunakan metode demonstrasi. Kendati dalam beberapa bencana seperti bencana gempa bumi lebih tepat menggunakan metode simulasi. Hal ini disebabkan oleh banyak factor. Bencana tanah longsor datang secara tiba-tiba dan langsung mengena ke materi 88 
yang di timpanya. Meskipun pada awalnya penulis meragukan hal tersebut karena longsor tetap memiliki tanda - tanda tertentu.

Hasil penelitian ini mempertegas teori behaviorisme, kontruktivisme dan teori Bruner. Dalam teori behaviorisme teori belajar ini sangat menekankan pada perilaku atau tingkah laku yang dapat diukur atau diamati. Demikian pula tentang kerucut pengalaman dari Edgar Dale yang menjelaskan bahwa rentangan tingkat pengalaman dari yang bersifat langsung hingga ke pengalaman melalui simbol-simbol komunikasi dari yang bersifat kongkrit ke abstrak.

Teori belajar kontruktvisme akan membangun pemahaman konsep geografi melalui pengalaman yang dialami oleh peserta didik. Semakin kuat pengalaman itu berkesan dalam diri peserta didik, maka akan semakin tinggi pula tingkat pemahaman peserta didik itu sendiri. Pemahaman konsep geografi yang sangat dekat keserharian peserta didik harus dimaksimalkan menjadi stimulus dalam proses pembelajaran geografi yang bertujuan meningkatkan kemampuan pemahaman konsep geografi.

Metode demonstrasi merupakan metode penyajian pelajaran dengan memperagakan dan mempertunjukkan kepada peserta didik tentang suatu proses, situasi atau benda tertentu, baik sebenarnya atau hanya sekadar tiruan. Sebagai metode penyajian, demonstrasi tidak terlepas dari penjelasan secara lisan oleh guru. Walaupun dalam proses demonstrasi peran peserta didik hanya sekadar memerhatikan, akan tetapi demonstrasi dapat menyaapabilan bahan pelajaran lebih konkret. Dalam strategi pembelajaran, demonstrasi dapat digunakan untuk mendukung keberhasilan strategi pembelajaaan ekspositori dan inkuiri.

Kelemahan demonstrasi yang dijumpai di lapangan, ketika guru mendemonstrasikan suatu proses tertentu, guru harus beberapa kali mencobanya terlebih dahulu, sehingga dapat memakan waktu yang banyak. Demonstrasi memerlukan peralatan, bahan-bahan, dan tempat yang memadai yang berarti penggunaan metode ini memerlukan pembiayaan yang lebih mahal dibandingkan dengan ceramah.

Simulasi sebagai hipotesis awal diduga lebih tepat dibandingkan dengan demonstrasi namun demikian kelemahan dalam penerapan metode ini tampak nyata terjadi pada beberapa kelompok. Pengalaman siswa di lapangan hanya mengalami amblasan tanah, namun untuk tanah longsor hanya beberapa siswa saja yang pernah mengalami hal ini tentu saja membuat simulasi berjalan kurang tepat dan sesuai dengan kenyataan di lapangan.

Keterbatasan peneliti adalah sempitnya waktu berkomunikasi dengan siswa dan kurang memperoleh gambaran siswa yang cerdas namun tidak pemalu dan sebaliknya ada siswa yang pemalu padahal dia tergolong cerdas. Beberapa variasi simulasi tidak tergambar dan monoton 
pada jalan cerita yang sama. Faktor psikologis seperti rasa malu dan takut sering memengaruhi peserta didik dalam melakukan simulasi .

\section{KESIMPULAN DAN REKOMENDASI}

\section{A. Kesimpulan}

Hubungan antar variabel yang ditunjukan untuk menjawab pertanyaan penelitian telah terjawab dalam bab pembahasan dan hasil penelitian. Terdapat perbedaan antara hasil pretes dan post tes pada metode simulasi yakni sebesar bahwa signifikansi sebesar 0,032 lebih kecil dari 0,05. Pada hipotesis kedua terdapat perbedaan antara hasil pretes dan post tes pada metode demonstrasi dengan taraf signifikansi sebesar 0,000 lebih kecil dari 0,05. Selanjutnya dapat pada hipotesis ketiga diketahui bahwa signifikansi sebesar 0,000 lebih kecil dari 0,05 maka $\mathrm{H}_{0}$ ditolak. Kesimpulannya yaitu Ada perbedaan hasil belajar pada kelas eksperimen yang menggunakan metode simulasi (PostSimulasi) dan kelas kontrol yang menggunakan metode demonstrasi (PostDemonstrasi). nilai Mean Rank Metode Simulasi sebesar 22,14 dan Mean Rank metode Demonstrasi sebesar 45. Jadi hasil belajar pada kelas kontrol yang menggunakan metode demonstrasi lebih besar dari pada metode simulasi.

\section{B. Rekomendasi}

Rekomendasi pertama ditujukan kepada pengambil kebijakan, pemahaman konsep geografi tidak semuanya dapat dilakukan dengan metode simulasi. Dalam hal ini terbukti konsep tanah longsor tidak tepat menggunakan metode simulasi. Selanjutnya, rekomendasi ditunjukan kepada lingkungan sekolah peserta didik. Perlu penekanan dengan mengunakan metode demonstrasi dalam proses pembelajaran karena daerah penelitian tergolong labil. Rekomendasi untuk peneliti lain terkait dengan hasil penelitian ini. Penelitian ini tergolong quasi eksperimen Sehingga memungkinkan timbul kelemahan dalam pengambilan data. Hal tersebut merupakan kesempatan untuk peneliti lain meneliti variabel-variabel lain yang berpengaruh terhadap pemahaman tanah longsor.

\section{DAFTAR PUSTAKA}

Alhusin, Syahri, “Aplikasi Statistik Praktis dengan Menggunakan SPSS 10 for Windows”, Edisi Kedua, Yogyakarta: Graha Ilmu, 2003. 
Arikunto.1986. Prosedur Penelitian edisi IV.jakarta ; rineka cipta

Arikunto, S. (2003). Dasar-Dasar Evaluasi Pendidikan. Jakarta: Bumi Aksara.

Azwar, Saifuddin. (1999). Penyusunan Skala Psikologi. Yogyakarta: Pustaka Pelajar.

Bahri.Syaiful.(2002).Strategi Belajar Mengajar.

Bruce joice.2011.Models teachinga (model-model pengajaran). Yogyakarta : Pustaka

Direktorat Tenaga Kependidikan Direktorat Jenderal Peningkatan Mutu Pendidik Dan Tenaga Kependidikan Departemen Pendidikan Nasional .(2008)Strategi Pembelajaran Dan Pemilihannya. Depdiknas Jakarta

Dwiningrum,Astuti( 2010). Sosialisasi Pendidikan Mitigasi Pada Lingkungan Rawan Bencana.Yogyakarta. UNY.tidak diterbitkan

Departemen Pendidikan Nasional

Ghazali, Imam, 2005, Aplikasi Analisis Multivariat Dengan Menggunakan Program SPSS, Universitas Gajah Mada Press, Yogyakarta.

Kusnendi. (2007). Model-Model Persamaan Struktural; Satu dan Multigroup Sampel dengan LISREL. Bandung. Alfabeta.

Maryani E.(2010). Model Pembelajaran Mitigasi Bencana Dalam Ilmu Pengetahuan Sosial Di Sekolah Menengah Pertama*).jurnal gea.10.no 1.2-17

Maryani.E.(2006)."Pendidikan Geografi" dalam ilmu dan aplikasi pendidikan. karangan Muhammad Ali dkk.Bandung : Pedagogiana Press

Mutakin, A. 2010.metode Penelitian Geografi. UPI Bandung Nasution. 1982. Didaktik Asas Mengajar. Jemmars: Bandung

Pusat Bahasa Depdiknas.2001. KBBI.Balai pustaka : Jakarta 